\title{
Dramatic Networks: Marginalized Economics and Labour in the Norwich Grocers' Play
}

\begin{abstract}
Using actor-network theory, this essay argues that the Norwich Grocers' Play creates a dramatic network among the city of Norwich, the actors of the play, and the marginal audience members from Norwich and its surrounding countryside when read in light of the Norwich Corporation assembly minute of 1527 and the history of social unrest culminating in Kett's Rebellion of 1549. The staging, costuming, and language of the play all function to ally the audience with the salvation history presented in the play and, in so doing, ensure the continued peace and prosperity of Norwich in the later 1560 s despite challenges that could have led to unrest mirroring that experienced in the 1540s.
\end{abstract}

The Norwich Grocers' Play is all that remains of what scholars believe was once probably quite an impressive cycle. As one pageant within what had been a larger play, the Grocers' Play serves as one element of a larger collective about which we know only through guild and assembly records of the city. We have no way of knowing what the other texts of the pageants may have looked like, and so our conclusions all come from this extant pageant. The cycle that included the Grocers' Play was an important economic event within the city of Norwich - so much so that the guild of St Luke petitioned the Norwich Corporation assembly to require other guilds to take up their fair share of responsibilities for putting on the play seeing as they all directly benefited from its performance. Worsening economic conditions as a result of land enclosure contributed to Kett's Rebellion of 1549 in Norfolk, which complicated Norwich's relationship with the surrounding countryside of Norfolk. Following Bruno Latour's call in actor-network theory to trace associations, I argue that the Grocers' Play was an important actor within the economic collective of Norwich and its surrounding areas in the sixteenth century. The Norwich Corporation assembly minute presents an economic

Jeffery G. Stoyanoff (jstoyanoff@shc.edu) is an assistant professor in the department of English and writing at Spring Hill College. 
network that relied on the commerce resulting from the cycle. Indeed, I contend that this commerce was so important to the city of Norwich that the B-text of the Grocers' Play, a revision produced in $1565,{ }^{1}$ uses affective techniques including staging and dialogue to align characters within the salvation history presented in the pageants with the marginal members of the audience from both urban and rural locales. This staging and the language create a dramatic network, encouraging the audience to identify with the important actors of biblical history. The Grocers' Play therefore both ensures the commerce produced by the cycle and maintains the peace and prosperity of the decades following the tumult of the 1540s in Norwich and Norfolk.

In Reassembling the Social, Bruno Latour describes the 'social' as 'what is glued together by many other types of connectors', and argues that we 'consider social aggregates as what should be explained by specific associations provided by economics, linguistics, psychology, law, management, etc'. ${ }^{2}$ For those of us concerned with medieval drama, this shift in how we are to understand and to interpret 'social' creates opportunities for new readings that perhaps question existing notions of the associations among guilds, pageants, cities, actors, etc. A good deal of recent criticism surrounding the cycle plays and guild culture has already, of course, begun to question such notions. ${ }^{3}$ When Latour adds, 'Even though most social scientists would prefer to call "social" a homogeneous thing, it's perfectly acceptable to designate by the same word a trail of associations between heterogeneous elements', ${ }^{4}$ I cannot help but think of the multivalent relationships involved in the production and reception of medieval drama. Instead of considering how these elements fit into some type of pre-existing whole, we can focus on what they create in interacting with each other. Social becomes an adjective indicating a type of connection that allows us to focus on realizations rather than expectations. As these connections become difficult to trace (particularly during moments of great change or fluctuation), however, Latour advocates 'it is no longer enough to limit actors to the role of informers offering cases of some well-known types. You have to grant them the ability to make up their own theories of what the social is made of. Your task is no longer to impose some order, to limit the range of acceptable entities, to teach actors what they are, or to add some reflexivity to their blind practice'. 5 Using Latour's model, I contend we can determine dramatic networks that drama - particularly medieval drama in this case - creates through relationships among actors, audience, and community. In the Grocers' Play, the text of the play, the actors, the guilds, the audience, and the space of the city itself all participate in this dramatic network. By tracing the actions that create this dramatic network, then, we can focus on particular relationships that such a network 
maintains and/or fosters. In this case, we can establish the economic and social impact of the Grocers' Play on Norwich and the surrounding countryside of Norfolk and vice-versa.

The Grocers' Play illustrates the importance of place and time in medieval drama, and through this affective presentation the play creates a dramatic network to benefit the economic and political interests of Norwich. Over fifty years ago, V.A. Kolve in his seminal work on Corpus Christi plays observed, 'The localizing of place must also be understood as part of the drama's interest in addressing its particular English audience in their particular moment in time, holding up to them a mirror of their own society and its moral nature. ${ }^{6}$ The Grocers' Play, then, concerns itself with sixteenth-century Norwich, and, as JoAnna Dutka writes, 'These texts of the Grocers' Play, the Grocers' Book in which they are found, and contemporary documents mentioning the mystery plays of Norwich, taken together, illustrate that the plays depended for their formation and development on the social and economic life of the city.' I would like to push Dutka's observation further to suggest this relationship goes both ways and that the city of Norwich's economic and political situation is also, at least partially, dependent upon the plays. Richard K. Emmerson convincingly argues, 'The text is only a trace of a complex historical event that involved players and assistants, civic and religious authorities, citizens and visitors, an event driven by and shaping a wide range of social, political, economic, and religious motivations. In short, it is a trace that does not mirror but only hints at a social event charged with all the complexity one would expect in a mobilized community. ${ }^{8}$ Without naming it as such, Emmerson outlines the dramatic network and the larger economic and social network of which any play is a part. More recently, Nicole R. Rice and Aziza Pappano claim, 'Like a dramatic production, artisan work was collaborative ... artisans worked together to produce their play, everyone playing a role, large or small, all intrinsic to the whole. Participation, timing, issuing and taking directions were ingrained practices for premodern artisans, schooled in precisely the cooperative mentality necessary for play production.? I believe we must take Rice and Pappano's point here one step further to add the audience to this collaboration. The lack of the fourth wall inherently includes the audience in the performance of the play using a variety of affective techniques. The Grocers' Play is no exception and uses such a dramatic network to achieve economic and political ends.

To better situate this concept, I turn to John J. McGavin and Greg Walker's magisterial Imagining Spectatorship: From the Mysteries to the Shakespearean Stage. ${ }^{10}$ McGavin and Walker do not use Latour in their argument about the relationships among play, actors, audience, and so on; however, the context of the 
production of these plays for which they argue serves to elucidate the potential for the larger dramatic network that I posit here. In their discussion of the York cycle, particularly 'The Crucifixion', McGavin and Walker argue that an audience member's perspective would have depended on their proximity to the stage and that this relationship, in turn, fundamentally shapes the affective responses available to them. ${ }^{11}$ They continue,

where one stands or sits has an effect on one's experience of a play that is variously practical, cultural, and aesthetic, and so needs to be taken into account alongside those other profound variables of gender, class, age, race, belief, or occupation that may have inflected an individual's response to drama such as this. Both socially inflected and embodied cognitive aspects of audience response would have been affected and inflected by physical location, and all of these factors need to be folded into our analysis of spectatorial experience. ${ }^{12}$

Following McGavin and Walker's lead, then, it seems reasonable that those involved in the production of such a play would be intimately aware of these factors and, indeed, would use them to one affective end or another. Later in their text, McGavin and Walker query the Reformation's role in the reception of the mystery plays, and for the Grocers' Play this issue is of especial concern considering the B-text revision occurred in 1565 . They suggest, 'the plays of this period seem to us more a matter of compromise than cultural paradox, of a necessary and skillful composition with the figured capacities of those who will watch the plays, in order to persuade them, through recognizable but transformed genres of performance, that their fundamental spiritual goal of salvation, which Protestants shared, after all, with Catholics, could be achieved by reformed routes'. ${ }^{13}$ Both of these arguments apply directly to the Grocers' Play, and yet it is the methodology of McGavin and Walker that interests me the most. If such plays might use revision to anticipate changing attitudes of faith, might they not also use it to anticipate and to affect other attitudes, including those of class? The audience, as McGavin and Walker masterfully argue, influences the play as much as it influences them, and both the audience and the play are part of the larger dramatic network that includes both historical and economic contexts.

The guild of St Luke's complaint in the minute of the assembly of the Norwich corporation from 21 September 1527 suggests that the guilds producing Norwich's pageants were well aware of important dramatic networks created and maintained by these performances. Through this document, we see the important economic impact of the Norwich cycle and the economic potential and/or 
gain that the city and its guilds could achieve by forming a dramatic network among Adam and Eve, labourers, and visitors from outside of the city. Norman Davis explains the initial petition from the guild of St Luke: 'On this occasion a petition was presented by the Guild of St Luke, an association of painters, braziers, plumbers, and other crafts, which had "of long time past" been responsible for presenting pageants on the Monday and Tuesday of Pentecost Week. The cost has almost ruined the guild, which therefore asked the Corporation to order that each "occupation" in the city should in future provide a pageant. ${ }^{14}$ The reason the guild requests that other guilds assist in the production of the play comes down to economics on two levels: bankruptcy and the shared economic benefit the cycle brings to the whole city. The guild of St Luke argues that the pageants it has put on

have ben and yet is so covetid specially by the people of the countré, by force wherof yerly at that tyme more than any other tyme of the yere the people of the countré haue abundauntly vsed to resorte to the said Citie, by reason of which resorte of people as well many merchaundises as vitaulle by the citezens and inhabitauntes withyn said Citie yerly more at that tyme than eny other tyme in the yere arn vttered and sold, to the grette releeff, socour, aide, and comfforte of the citezens and inhabitauns. ${ }^{15}$

While the guild of St Luke paid the costs of producing the cycle, all of the guilds and the city government benefited. The economics of the cycle also linked the city and its guilds with people living in rural areas outside of the city. The people on the margins of Norwich visited the city during Pentecost week to see the pageants, bringing with them an influx of money spent on merchandise and food (victuals). These country people were a large economic boon for the city. The discussion the minute records occurred more than twenty years before the events of Kett's Rebellion, which I will discuss below, yet this document recognizes the economic impact of a dramatic network made up of people from within and without the city. Additionally, the minute expresses how all people, but especially the country people, coveted these performances, and qualifying these performances thus further suggests the affective potential of these plays that may be used for economic and political purposes.

Twenty years later in the mid to late 1540 s, the economic depression that began in the earlier decades of the sixteenth century took hold of the workingclass, urban and rural. Many of the people who would have previously attended the performances in Norwich faced economic hardships that likely jeopardized their ability to do so, marginalized both by their class status and their shrinking 
roles in a changing economy. ${ }^{16}$ Discussing a similar situation in Wakefield, Sturges remarks, 'The manorial peasant is not ... merely the victim of unalterable circumstances that can only be accepted with resignation; instead, he is now victimized by an identifiable class and expresses his class resentment directly'. ${ }^{17}$ The circumstances the peasantry in Norwich faced became more dire as the sixteenth century progressed due to land enclosure and the dissolution of monastic houses. ${ }^{18}$ For wage labourers in both rural and urban Norfolk, wages remained stagnant as prices of goods rose over fifty percent. ${ }^{19}$ The price of wheat, for example, quadrupled from four shillings a quarter in 1547 to sixteen shillings in 1549, yet wages were nearly stagnant in comparison with only a modest increase from four pence half-penny to five pence. ${ }^{20}$ This economic squeeze eventually exploded into Kett's Rebellion of 1549, of which a major complaint was 'the gifts of God in Nature were made to man and not to landlords only'. ${ }^{21}$ Enclosure in Norfolk resulted in over 300,000 land workers being 'thrown out of work' and tenant farms losing pasture for sheep and bullocks by $1548 .^{22}$ The peasants under Kett's leadership held Norwich briefly before they were defeated, and nearly three thousand peasants died. ${ }^{23}$ With these troubles in recent memory, the occasion of the play ensured stability between the governing class of the city and its working class as well as the rural peasantry of the surrounding countryside. There likely would not have been a better symbol for this union than the leather apron worn by labourers, city and country alike.

Kett's Rebellion of 1549 and its foundations directly affected the dramatic network that includes the Grocers' Play. Kett's Rebellion's roots in fact began with a performance of the Life of St Thomas Beckett in July 1549 and the networks of actors that emerged from it. ${ }^{24}$ The Grocers' Play results from and participates in a dramatic network that includes rebellion. I quote Andy Wood here at length for his description of the relevant events that created such a network:

On Saturday 6 July [1549], crowds gathered at Wymondham to watch the Wymondham Game, a traditional play which celebrated the life of St Thomas Becket. This was itself tinged with sedition, since the commemoration of the life of St Thomas Becket had been outlawed under Henry VIII. The feast day of Wymondham Gate took place on the Sunday; and the festivities ended on Monday 8 July. But, inspired by the news that rebels in Kent had risen, commotioners in Norfolk used the opportunity of the Wymondham Game to organise an insurrection of their own. Thomas Becket may have had a special importance for Tudor insurrectionaries ... Again, as evidence of the links between urban and rural commons that characterised the 1549 rebellions, plans for the Wymondham rising also drew in the poor of Norwich. ${ }^{25}$ 
This play served as a nucleus out of which Kett's Rebellion grew. That is, those working-class labourers and poor who took part in the uprising seem to have identified something in this performance that encouraged their own actions or, at least, to have used the occasion as an opportunity to stage their protest. Wood explains social interactions of this period that might even contribute to such a network: 'the status quo is reaffirmed not only through overt state propaganda but also through daily patterns of social interaction between dominators and dominated. Thus, the everyday emerges as the essential site within which a ruling class must maintain its authority. ${ }^{26}$ The social interactions between the ruling class and the peasantry, then, are not a pageant or a play, and yet they are equally a part of the dramatic network of the Grocers' Play. They inform and are informed by the cultural setting for the play. Wood additionally addresses the role of other actors in this dramatic network through the 'enclosure commissions of 1549', which nods to 'the increasing inclusion of the commons within a polity which was supposed to be closed to popular politics. This contradiction was to be blown open by the rebellions of 1549 '. ${ }^{27}$ And yet, Wood concludes, 'Kett's defeat left the rebellious commons traumatised and broken'. ${ }^{28}$ The trauma of this defeat would not have dissipated quickly, nor, does it seem, was it isolated to the commons.

The grievances of the uprising had their roots in complaints aligned with the rural peasantry, yet many of the rebels came from outside of this class. Artisans and landowners, too, took part in Kett's Rebellion. ${ }^{29}$ Robert Kett himself was not a member of the working class; he was an artisan - specifically, a tanner. That he took on the cause of the rebels is one of the more curious turns in these uprisings, supporting my argument about this dramatic network consisting of labourers, the play, and Norwich. Barrett L. Beer explains, 'Although no information about his tannery has survived, it is likely that Kett was the only tanner in Wymondham as well as one of the town's leading tradesman. Tanning was an essential craft, serving shoemakers, farmers, and manufacturers. The leather industry of Tudor England was more important than the metal crafts and ranked second to the woolen cloth industry'. ${ }^{30}$ If my supposition here is correct and the leather aprons in the play are meant to symbolically represent something beyond their suggestion of labour, Kett's being a tanner is another crucial piece of this puzzle. The leather apron could recall the events of 1549 in a similarly tumultuous 1560 s decade of the B-text's production. Anthony Fletcher and Diarmaid MacCulloch caution us that the accounts of 1549 that remain are inherently biased — in particular, they suggest Nicholas Sotherton's account 'may be deceptive' and 'his account is designed to minimise, explain away or obscure the close involvement of the city authorities with the commotions. ${ }^{31}$ Later, Fletcher and MacCulloch opine, 'The 
events at Norwich in July and August 1549 indicate one of the most extreme breakdowns of trust which Tudor England experienced between the governing class and the people who normally sustained local government'. ${ }^{32}$ The memory of these events must have loomed large in the immediate decades after 1549, and the distrust of government, particularly local government, continued well into the 1560s.

The unrest of the 1540s did not plague the subsequent decades in either Norfolk or Norwich. The economic situation of those in the working class did not emphatically worsen, and there are no records of significant rebellion during this time. There are, however, a few significant factors during the 1550 s and 1560 s that lead me to believe that the Grocers' Play actively remembers the unrest of Kett's Rebellion and the potential economic implications first voiced in the assembly minute of 1527 . John Pound describes Norwich as experiencing an economic depression in its textile industry during the mid-sixteenth century, which was exacerbated 'from the influenza epidemic which swept the country in 1556'.33 Despite the depression in the textile industry in Norwich, Pound posits that records indicate the city was otherwise in financial health. One statistic he mentions is particularly provocative: 'At least 80 per cent of the freemen were engaged, directly or indirectly, in providing goods for the consumer, and it is hardly possible to envisage four people producing goods for the other one. ${ }^{34}$ Norwich, Pound suggests, had become 'a lesser London', 35 and such economic success would set in sharp relief the tumult of the previous decades. The relative economic success of the city, however, should not overshadow other noteworthy changes. In particular, the leadership of the city shifts heavily toward Protestantism after the flu epidemic, and there is an influx of immigrants from the Netherlands during the early 1560s, changing the demographics of the textile industry. ${ }^{36}$ Both of these changes call to mind the type of cultural changes that occurred in the buildup to the unrest of the late 1540s, culminating in Kett's Rebellion. ${ }^{37}$ The Norwich Grocer's Play, then, could serve an important cultural and civic role in this context, but it seems the Grocers' guild had its own financial concerns to attend to at this time, too. According to records compiled by Dutka, the Grocers' account is inactive from 1548-55, resuming in 1556, and in 1563, 'The Grocers' Pageant is ordered to be prepared for the coming mayoralty inauguration'. ${ }^{38}$ The directive for the B-text comes in 1565. ${ }^{39}$ In light of this data, the play's production (off and on) from 1555-65 was subject to the same financial constraints that affected it since the early decades of the sixteenth century. The 1565 B-text participates in the same dramatic network that engages economics and class as had its predecessors, building on its immediate cultural and historical contexts. The B-text 
of the Grocers' Play presents a dramatic network by associating Adam and Eve with the audience to benefit the city both economically and politically in light of the unrest in prior years. The play uses affective techniques to advocate equality among all members of the audience in service of assuaging the potential tensions between the ruling class and the working class. After Adam and Eve have both eaten the forbidden fruit from the Tree of Knowledge, the Father reprimands them and sentences them to a life of labour:

Thy lyvyng shall thou get with swett unto thy payne,

Tyll thou departe unto the erth wherof I dyd the make.

Beholde, theis letherin aprons unto yourselves now take. $(92-4)^{40}$

The first point worth mentioning here is that these lines, though ostensibly spoken to Adam and Eve, might also apply to the audience at large. Adam and Eve shall make their living by sweat and pain until they die, and this type of language focused on earthly toil would have been common rhetoric. The association of leather aprons with this labour, however, is unique to the Grocers' Play. ${ }^{41}$ 'Beholde' indicates that the Father gestures toward the leather aprons. This line holds three possible important interpretations. First, the Father could simply gesture toward leather aprons as props, indicating that Adam and Even must wear these aprons now that they must labour. The latter two possible interpretations rest on the use of 'Beholde' as indicating a group of people. In this case, then, 'letherin aprons' refers to groups of people. On one hand, the leather aprons may indicate the guild members who are putting on the pageants as a bit of selfdeprecating humour; however, these same aprons may also refer to the audience members beyond the guilds, including farmers and labourers. This latter potential is especially symbolic given the fraught history of enclosure and rebellion. The act of enclosure itself echoes the expulsion of Adam and Eve from Paradise, and the rebels of Kett's Rebellion were more than expelled from the city - they were massacred. The rest of the line in this reading indicates that Adam and Eve should join their company. Adam and Eve literally join the ranks of the labourers as a result of the Fall.

Even though God does not provide clothing to Adam and Eve in the York and N-Town pageants of the Fall, this moment in the Grocers' Play has its precedent in the Bible and the Chester 'Play of Adam and Eve'. The Grocers' Play, however, emphasizes the agency of Adam and Eve as actors in this moment through an important, if subtle, difference: they must take up the garments and clothe themselves to mark their newfound labour. In the biblical account of the Fall, God clothes Adam and Eve in animal skins: 'And the Lord God made for Adam and 
his wife, garments of skins, and clothed them'.42 In the Chester 'Play of Adam and Eve', too, God clothes Adam and Eve: 'Then God, putting garments of skin upon them:). ${ }^{43}$ In both accounts, God clothes Adam and Eve, but in the Grocers' Play, God merely presents the leather aprons to Adam and Eve. In the York version of this pageant, God references only the labour Adam and Eve have chosen for themselves: 'In erthe than shalle ye swete and swynke / And travayle for youre foode' (161-2). ${ }^{44}$ In the N-Town pageant, God expressly tells Adam that he (and Eve, one assumes) should suffer their nakedness in their labour:

Go teyl pi mete with synk and swoot

in to pi lyvys ende

Goo nakyd vngry and bare ffoot

We can see in the biblical account and the four dramatic accounts, labour and toil are the main punishment for Adam and Eve. The Grocers' Play differs from the Bible and the Chester play in two crucial ways: first, the animal skins have become leather aprons. Such aprons would indeed have been made from animal skin, but an apron requires extra processing — extra labour. ${ }^{46}$ Second, Adam and Eve must put the leather aprons on themselves - God does not clothe them in this version. This dramatic choice in the Grocers' Play both acknowledges that Adam and Eve have fallen through their decision to disobey God and that the leather apron is synonymous with the toil and hardship of work in a fallen world that one must engage.

Beyond the leather aprons, the Grocers' Play offers further evidence that Adam and Eve are associated with the audience through a stage direction and use of pronouns. The stage direction physically moves Adam and Eve to the margins of the stage after the angel's lines that officially cast Adam and Eve from Eden: 'Then Man and Woman departyth to the nether parte of the pageant' (101-2). If we assume that the 'nether parte' of the pageant is outside of Paradise where the Father resides at the pageant's beginning, Adam and Eve move closer to the audience at this moment; furthermore, the margins of the pageant wagon are a physical parallel to the margins of the city and a symbol of the economic margins. The physical parallel creates an association with those in the audience who would have come into the city for the event. The economic symbolism here, though, is a bit more complicated. This staging might remind the audience of the sacking of the city during Kett's Rebellion, or it could potentially remind the urban poor of their own involvement as they joined the outside rebels in their attack on the gentry. After this move, Adam and Eve begin to adopt first-person plural pronouns. On one hand, this shift in language demonstrates that they are both together now 
fallen; however, this use of a plural pronoun may serve as an affective move to include the audience in the fall/fallenness. Adam exclaims, 'Oh! what have we lost! Why did we no more care, / And to what kynde of place shall we resort and goo'? (106-7). The repetition of 'we' places blame on humankind, and the word 'kynde' alludes to the mortal dwelling of humankind and the universal nature of original sin in Christian theology. Eve's response reinforces this reading:

Indede into the worlde now must we to and fro,

And where or how to rest, I can nott say at all.

I am even as ye ar, what so ever me befall.

Eve notes that she and Adam must go into the world as they have become mortal, and she expresses that they will not be able to rest, moving often. This first line may simply refer to labour and the trials and tribulations that Adam and Eve's line will face before Christ's coming, or it may indicate movement in and out of a place. The following line emphasizes the restlessness and the unceasing labour of the fallen world. But the third line is critical because Eve uses the pronoun ye. This form could indicate polite deference to Adam $;{ }^{47}$ however, it is also the second-person plural pronoun of address in Middle English. ${ }^{48}$ By saying that her current state is that of those around her (the audience), Eve confirms that the staging shift intends Adam and Eve's identification with the audience. This identification creates an important affective association for the success of the play (the Holy Ghost, Pentecost, etc.), but an ulterior economic association may be read here, too, that uses this dramatic network to the guilds' and Norwich's benefit.

The dramatic network that the Grocers' Play enables, however, poses potential problems, particularly further economic exploitation of an already-exploited class. The words 'to and fro' also describe the audience's movement to the play space for the staging of the play. On the one hand, the audience members from the surrounding countryside indeed have moved into the city for the play and will leave it once the play has ended. These members of the audience are welcome as long as the cycle is performed, particularly because they bring with them the revenue upon which the city relies. The audience members who are residents of Norwich and associated with Adam and Eve via staging and perspective - the working class and poor - are welcomed at the play even though they are not part of the government of the city. Both groups are equal members of humanity for the duration of the play. But the audience will eventually be expelled from Norwich just as Adam and Eve were expelled from Paradise. The potential for further economic exploitation exists here: the peasantry and working class are only useful for the money that they bring to the city through the play. Perhaps the dramatic network 
of the play extends to them only as long as the play performs it. In Kett's Rebellion, the urban and rural peasants were not only expelled from Norwich, they were executed, and so with this violent past in mind the guilds used the affective moment of the play as an attempt to express solidarity. Rice and Pappano note, 'The cycle plays worked to bolster artisanal claims to local identity: they produced and reproduced artisans' notions of themselves as not only belonging but commanding the very terms of belonging to a particular space, inserting themselves in the city's providential history and recreating civic space as they paraded through the city streets. ${ }^{49}$ The Grocers' Play includes its audience as part of the dramatic network it forms and, in so doing, it follows that the audience is privy to the providential history reenacted in the play. The city benefits from the spending of the working-class people who attend the performance, and so it makes sense that the guild welcomes them during the performance and wants them to feel invited for all future performances. This inclusion is of course symbolic; it is an affective gesture to make the otherwise disenfranchised believe they have been included as equals in the whole of Norwich.

Beyond the economic ends achieved by the stage direction and pronouns that ally Adam and Eve with the audience, the remainder of the play uses this dramatic network to include the audience in an expedited salvation history. This moment serves both as a way of repaying their patronage and as a method of addressing the parallels between the experiences of the working class and those of Adam and Eve. The Norwich cycle is the only major cycle that does not include pageants of the passion. ${ }^{50}$ After the Fall, Dolor and Misery take Adam. Misery's lines suggest that the fallen state of Adam, and vicariously that of the audience, is deserved: 'Accordinge to desarte thy portion is, of right, / To enjoy that in me that is withoute certentye' (117-18). Misery asserts that only Adam has been expelled from Paradise into the world that lacks the assured protections and benefits that he had before falling. This moment again recalls events from the recent past that might echo the expulsion from Paradise for the working-class audience members who remember or participated in rebellion. In particular, the first line's use of 'desarte' allows some rich translation possibilities. The usage here mostly likely suggests the reading I have suggested above, yet the word with this spelling here usually refers to an uninhabitable area. ${ }^{51}$ In that case, we are brought to land imagery again and the potential lack of arable land for Adam and Eve to farm. The peasanty of Norfolk experienced the same lack of arable land. This lack of land would indeed be a sense of misery for them, and by acknowledging that misery, the play may be moving from exploitation to reconciliation by staging this moment in service of those members of the audience who have had such an experience. 
The play does not linger on this moment, however, and the Holy Ghost comes to Adam and Eve's aid. The play presents this aid as available to the audience, too. Adam bemoans their fallen state in which he says, 'must we lerne owr lyvynges to gett. / With labor and with travell; ther is no remedye, / Nor eny thyng therfrom we se that maye us lett' (120-2). Here, again, Adam's use of the first-person plural pronoun 'we' points directly to him and Eve. Considering the ambiguity of the pronoun's antecedent earlier, however, this moment may also be read as an affective complaint meant to appeal to the shared experience of hard labour with the audience. The last line serves potentially two purposes - it could speak to insufficiency of the material world or, more likely I think, it serves as a cue of sorts for the Holy Ghost to appear. Adam's use of the verb suggests that the Holy Ghost is not yet on stage but also that what will 'lett' 52 - grant them a reprieve - is invisible, immaterial. It can only be the Holy Ghost. Once the Holy Ghost appears, the shift from fallenness to salvation is immediate. The Holy Ghost explains that this has just been a trial (127-9) and later adds, 'I wyl be thy guyde and pay the thy hyer / For all thy good dylygence and doenge thy dewe' (132-3). Critics rightly note that the inclusion of the Holy Ghost is a play on the theme of felix culpa, demonstrating the eventual salvation that comes after the birth, passion, and resurrection of Christ. ${ }^{53}$ But the language in the lines above also presents economic implications. The Holy Ghost speaks to 'Man', but he also speaks to humankind in this allegorical moment. He explains that he will 'pay the hire' - that is, save — those who have laboured here on Earth but this reward has already resulted from the dramatic performance. This notion is in opposition to what Misery said only lines earlier about Adam and Eve getting their just deserts. The audience as part of this dramatic network is in the end rewarded for paying to see the play. When the Holy Ghost refers to the Pauline armour as 'theis armors' (137), the stage prop may potentially be the same 'letherin aprons' that the Father references about forty lines earlier (94). The records do not include a separate line item for armour costuming. ${ }^{54}$ This potential exists when we consider what Dutka has called 'the author's fondness for parallelism.. ${ }^{55}$ By transforming the symbol for labour via fallenness into protection to gain salvation, the play affectively provides a promise of salvation through labour and a path to this message of salvation through the dramatic network it provides. The salvation that the play offers seems to also be a way of diffusing any possible tensions created earlier by resonances, intentional or otherwise, to enclosure and rebellion.

The final stanza of the play joins the actors and audience in song in a final effort to bring the play's salvific message to bear on the whole audience despite 
past and current inequities evidenced in the dramatic network. The song shifts temporal concerns to the expectation of the resurrection:

With hart and voyce

Let us reioyce

And prayse the Lord alwaye

For this our joyful daye,

To se of this our God his maiestie,

Who hath given himsellfe over us to raygne and to governe us.

Lett all oure hartes reioyce together,

And let us all lifte up our voyce, on of us with another.

The song brings the voice of the audience into the space of the play to celebrate the resurrection that has saved them from their fallenness and misery. The reign here is heavenly rather than earthly and incorporates all of the audience and Norwich now that the Holy Ghost has provided the Pauline armour promised in Christ's crucifixion and resurrection. Dutka asserts, 'The play can have no other ending but the song' due to the 'the playwright's figurative treatment of his story'. 56 'The play fulfills the parallelism between the Fall and the Resurrection, but it also releases the tensions of the dramatic network in which these biblical events are paralleled in the local, historical events of Norwich and Norfolk. The final line qualifies the voice of song as one voice of all singers together. It fittingly alludes to the dramatic network of economic and political past and present, channelling song as a symbol of harmony to undo discord.

The Grocers' Play participates in a dramatic network that places the history, economics, and politics of Norwich in conversation with the biblical events portrayed in the play. The affective techniques allow guilds and the city of Norwich to profit; however, in the end, the connections forged are even greater than that. Considering the contentious economic and political history of Norfolk and Norwich, the Grocers' Play, by the time of its 1565 revision, may have been a civic measure to ensure the peace and prosperity of the city in the face of addition changes with the potential to foment again social unrest like that of the later 1540s. The audience members whose perspective would have led them to associate themselves with Adam and Eve were the urban and rural labourers - marginalized both economically and politically. The Grocers' Play offers potential atonement through engaging them via its dramatic network. Undoubtedly, the guilds and city of Norwich profited from those labourers on the economic and class margins of the city, and there is clear evidence that the play seeks to unite these labourers with Adam and Eve, wearing the leather aprons of labour in the 
fallen world. Perhaps the economic boon is a secondary focus for the city, and it instead aims to quash dissent through a symbolic gesture. The immediate present of the workers and poor may not be paradise, but such symbolic solidarity of all workers clad in the Pauline armour of leather aprons hopes for the life of the world to come. The dramatic network of the Grocers' Play uses its affective power to convince these leather aprons to wait for the Holy Ghost to relieve them of their toils to grant promised salvation. 


\section{Notes}

I would like to express my gratitude to the anonymous reviewers who provided generous and detailed feedback to the initial draft of this essay. I must additionally thank the Sewanee Medieval Colloquium, at which this argument was first presented, and Christina Fitzgerald, who served as panel respondent, for her suggestions and encouragement.

1 For the purposes of this essay, I am referring to the B-text of the Grocers' Play when I write the Grocers' Play.

2 Bruno Latour, Reassembling the Social: An Introduction to Actor-Network Theory (New York, 2005), 5.

3 See, for example, Christina M. Fitzgerald, The Drama of Masculinity and English Guild Culture (New York, 2007), https://dx.doi.org/10.1057/9780230604995; Robert S. Sturges, The Circulation of Power in Medieval Biblical Drama (New York, 2015), https://dx.doi.org/10.1057/9781137073440; and Pamela M. King, 'The End of the World in Medieval English Religious Drama', Literature \& Theology 26.4 (2012), 384-99, https://dx.doi.org/10.1093/litthe/frs048.

4 Latour, Reassembling the Social, 5.

5 Ibid, 11-12.

6 V.A. Kolve, The Play Called Corpus Christi (Stanford, 1966), 113.

7 JoAnna Dutka, 'The Lost Dramatic Cycle of Norwich and the Grocers' Play of the Fall of Man', Review of English Studies 35.137 (1984), 2, https://doi.org/10.1093/res/ XXXV.137.1.

8 Richard K. Emmerson, "Eliding the "Medieval": Renaissance New Historicism and Sixteenth-Century Drama', James J. Paxson, Lawrence M. Clopper, and Sylvia Tomasch (eds), The Performance of Middle English Culture: Essays on Chaucer and Drama in Honor of Martin Stevens (Cambridge, 1998), 29.

9 Nicole R. Rice and Aziza Pappano, The Civic Cycles: Artisan Drama and Identity in Premodern England (Notre Dame, 2015), 25.

10 John J. McGavin and Greg Walker, Imagining Spectatorship: From the Mysteries to the Shakespearean Stage (Oxford, 2016).

11 Ibid, 13.

12 Ibid, 17.

13 Ibid, 132.

14 Norman Davis, Non-Cycle Plays and Fragments (New York, 1970), xxvi-xxvii. For more information on the Pentecost festivals and the role of the Grocers' Play in 
relation to them, see Joanna Dutka, 'Mystery Plays at Norwich: Their Formation and Development', Leeds Studies in English 10 (1978).

15 Ibid, xxvii.

16 I would not go so far as to argue causation in this event, but it is worth noting, as Dutka has observed, that starting in 1547 'The Grocers' Accounts fail until 1556'. See Dutka, 'Mystery Plays at Norwich', 115.

17 Sturges, The Circulation of Power in Medieval Biblical Drama, 90.

18 See Andy Wood, The 1549 Rebellions and the Making of Early Modern England (Cambridge, 2007), 24, https://doi.org/10.1017/CBO9780511496141. Wood explains, 'The dissolution of monastic houses and of the chantries, and the seizure of church lands and goods, were felt by many common people to represent an aggressive action by the Crown and the gentry, part of a wider assault upon the traditional social order'.

19 Ibid, 30. Wood notes, 'In 1547, prices stood at 46 per cent higher than they had in 1540. Prices fell in 1548, only to rise again in 1549 by 11 per cent on the 1548 average. By the 1550s, agricultural prices were 95 per cent up on those of the 1530s. Devastating as this was for landholding tenants, this surge in prices was catastrophic for the wage labourers who made up a growing population of the village economy of agrarian regions. The same was true of urban labourers'.

20 William Hunt and Reginald L. Poole (eds), The Political History of England in Twelve Volumes, 12 vols (New York, 1919), 6.30.

21 Ibid, 34.

22 Ibid, 29.

23 Ibid, 36-7.

24 Wood, The 1549 Rebellions and the Making of Early Modern England, 21.

25 Ibid, 60-1.

26 Ibid, 27-8.

27 Ibid, 40.

28 Ibid, 69.

29 See Perez Zagorin, Rebels and Rulers, 1500-1660, vol. 1 (Cambridge, 1982), 211. Zagorin explains, 'Even though its grievances were nearly all agrarian, the rebellion was a great popular demonstration that swept up peasants, rural artisans, and townfolk. One list of forty-seven participants mentions seventeen husbandmen plus assorted other occupations like butcher, tailor, laborer, miller, cooper, innkeeper, and mason'.

30 Barrett L. Beer, Rebellion and Riot: Popular Disorder in England During the Reign of Edward VI (Kent, Ohio, 2005), 86.

31 Anthony Fletcher and Diarmaid MacCulloch, Tudor Rebellions, rev $5^{\text {th }}$ ed. (Harlow, 2008), 72. 
32 Ibid, 82.

33 John Pound, Tudor and Stuart Norwich (Surrey, 1988), 54.

34 Ibid, 55. One is tempted to argue with Pound's assumption here given historical inequities in the distribution of wealth.

35 Ibid, 55.

36 See Matthew Reynolds, Godly Reformers and Their Opponents in Early Modern England: Religion in Norwich, c. 1560-1643 (Rochester, NY, 2005), especially chapter 3. Reynolds explains the political tensions resulting from the nexus of shifting religion, trade, and immigration that occur during Thomas Sotherton's mayoralty (48). See also David Galloway (ed), REED: Norwich, 1540-1642 (Toronto, 1984), 1.xvi. He notes, 'In 1565, thirty households of Dutch, Flemish, and Walloon weavers came to Norwich, and by 1579 there were about 6,000 aliens in a total population of over 16,000 '.

37 See Wood, The 1549 Rebellions and the Making of Early Modern England, particularly chapter 1.

38 See Dutka, 'Mystery Plays at Norwich', 115-16.

39 Ibid, 116.

40 Parenthetical citations reference 'The Norwich Grocers' Play', Norman Davis (ed.), Non-Cycle Plays and Fragments (New York, 1970).

41 In Fitch's transcription of the now lost manuscript of the play, he includes the following footnote to clarify 'letherin aprons': 'Unto the same Adam also, and his wife, did the Lord make lethern garments, and clothed them. (Grafton's Bible, 1553, "according to the translation of the Great Bible")'. See Robert Fitch, Norwich Pageants: The Grocers' Play (Norwich, 1856), 15.

42 Gen 3:21 DRB.

43 'The Play of Adam and Eve', Christina M. Fitzgerald and John T. Sebastian (eds), The Broadview Anthology of Medieval Drama (Peterborough, Ontario, 2013), 213.

44 'The Fall', Clifford Davidson (ed.), The York Corpus Christi Plays (Kalamazoo, MI, 2011), http://d.lib.rochester.edu/teams/text/davidson-play-5-the-fall.

45 K.S. Block (ed.), Ludus Coventriae or The Plaie Called Corpus Christi, Cotton MS. Vespasian D. VIII (Oxford, 1922).

46 The definition of apron in The Oxford English Dictionary Online (OED) lists the Coverdale Bible of 1535 as an important use of the word apron wherein Adam and Eve sow fig leaves together to make aprons. See $O E D$, apron, n. 1.

47 OED, pron. and n. 'ye' A.I.3.a.

48 OED, pron. and n. 'ye' A.I.1.a.

49 Rice and Pappano, The Civic Cycles, 20. Particular to Chester, they assert the performance of the cycle was 'a beneficent act that helped the city both spiritually and 
financially' (22). This logic would also likely apply to Norwich and, vicariously, its surrounding locales.

50 Davis, Non-Cycle Plays and Fragments, xxix-xxx.

51 The Middle English Dictionary, U Michigan, n. 1(a) 'desarte'. https://quod.lib.umich. edu $/ \mathrm{cgi} / \mathrm{m} / \mathrm{mec} / \mathrm{med}-i d x ?$ size $=$ First $+100 \&$ type $=$ orths $\& q 1=$ desarte $\& \operatorname{rgxp}=$ constrain ed.

52 The Middle English Dictionary, U Michigan, v.1 'leten'. https://quod.lib.umich.edu/ $\mathrm{cgi} / \mathrm{m} / \mathrm{mec} / \mathrm{med}$-idx?size=First+100\&type=headword\&q1=leten\&rgxp=constrained.

53 See Kevin J. Harty, 'The Norwich Grocers' Play and Its Three Cyclic Counterparts: Four English Mystery Plays on the Fall of Man', Studia Neophilologica 53 (1981), 88-9, https://dx.doi.org/10.1080/00393278108587799; and Dutka, 'The Lost Dramatic Cycle of Norwich and the Grocers' Play of the Fall of Man', 11.

54 See Davis, Non-Cycle Plays and Fragments, xxxv.

55 Dutka, 'The Lost Dramatic Cycle of Norwich and the Grocers' Play of the Fall of Man', 10. Additionally, Dutka notes, 'the allegory is not superfluous, but a striking means of illustrating the personal consequences to Adam of his disobedience' (10).

56 Ibid, 11. 
